\title{
Analisis Pro-poor Growth Melalui Identifikasi Pengaruh Pertumbuhan Ekonomi Terhadap Ketimpangan Pendapatan dan Kemiskinan Di Indonesia Tahun 2010-2015
}

\author{
Azka Muthia ${ }^{1}$ \\ ${ }^{1}$ Badan Pusat Statistik Kabupaten Banjar \\ azka.muthia@bps.go.id
}

\begin{abstract}
Economic growth, income distribution inequality, and poverty should have interdependent relationships with one another. In 2010 to 2015, Indonesia experienced a decrease in poverty but its economic growth slowed and the Gini ratio was stagnant. Therefore the author conducted research to analyze the influence of economic growth and income disparity on poverty eradication in Indonesia to find out the level of economic growth influence whether it is pro-poor or anti-poor and to find out the sectors influencing the poverty eradication. The panel data obtained from 33 provinces in Indonesia from 2010 to 2015 were analyzed. The result of this study showed that the economic growth had negative influence on poverty level. Based on the influence of elasticity value of net poverty on the economic growth, the economic growth can minimize the poverty. The economic growth in Indonesia for 2010-2015 was pro poor, but the value of gross elasticity and net poverty on Indonesia's economic growth is less elastic. As a result, poverty reduction driven by economic growth was not too large.
\end{abstract}

Keywords : pro poor growth, panel regression analysis, poverty

\section{Pendahuluan}

Menurut Todaro dan Smith [1] pembangunan ekonomi diperlukan apabila suatu negara ingin meningkatkan taraf hidup dan kesejahteraan rakyatnya. Karena tujuan utama dari proses pembangunan itu sendiri adalah meningkatkan standar hidup dan kesejahteraan masyarakat, mengurangi kemiskinan serta memperluas pilihan ekonomi dan sosial yang membebaskan masyarakat dari ketergantungan.

Pertumbuhan ekonomi, ketimpangan distribusi pendapatan, dan kemiskinan memiliki hubungan saling ketergantungan antara satu dengan yang lain. Todaro dan Smith [1] menyatakan bahwa setinggi apapun pendapatan nasional per kapita dan pertumbuhan yang dicapai suatu negara selama distribusi pendapatan tidak berjalan merata maka tingkat kemiskinan akan tinggi. Sebaliknya, meskipun distribusi pendapatan telah berjalan merata jika pendapatan nasional per kapita dan pertumbuhan rendah maka kemiskinan juga akan meluas.

Bourguignon [2] juga menyatakan bahwa pengurangan kemiskinan akan mampu berjalan lebih efektif jika pertumbuhan yang dihasilkan diimbangi dengan distribusi pendapatan yang lebih merata. Permasalahan yang terjadi bukan hanya bagaimana 
menumbuhkan perekonomian, namun juga bagaimana memaksimalkan kualitas dari pertumbuhan yang dihasilkan.

Masalah yang umum dihadapi negara berkembang seperti Indonesia adalah perekonomian didominasi oleh para pemilik modal. Penduduk golongan atas menjadi lebih dominan dalam menerima manfaat dari pertumbuhan ekonomi yang dicapai. Akibatnya permasalahan kemiskinan masih terjadi dan ketimpangan semakin besar.

Permasalahan kemiskinan dan ketimpangan pendapatan telah mendapat perhatian dunia. Deklarasi millenium development goals (MDGs) pada September 2000 menempatkan penanggulangan kelaparan dan kemiskinan sebagai tujuan pertama dari delapan butir tujuan yang disepakati. Untuk mendukung kesepakatan tersebut, pemerintah Indonesia menempatkan penanggulangan kemiskinan sebagai salah satu visi dalam rencana pembangunan jangka panjang (RPJP) 2005-2025 dan rencana pembangunan jangka menengah (RPJM) dengan sasaran utama mempercepat penurunan tingkat kemiskinan hingga mencapai 7-10 persen di akhir tahun 2014. Namun, pada Maret 2015 tingkat kemiskinan masih berada di angka 11,22 persen.

Berdasarkan data, pertumbuhan ekonomi Indonesia tahun 2010-2015 cenderung sedikit melambat dan diikuti dengan penurunan tingkat kemiskinan yang juga lambat. Meskipun terjadi pertumbuhan ekonomi pada periode tersebut, angka Gini rasio tidak mengalami perubahan. Berdasarkan penjelasan tersebut, maka penelitian ini perlu dilakukan untuk menganalisis faktor-faktor yang memengaruhi kemiskinan di Indonesia selama periode waktu 2010-2015 dan menganalisis kaitan pertumbuhan ekonomi dan ketimpangan terhadap kemiskinan menggunakan pro poor growth index (PPGI).

\section{Tinjauan Pustaka}

\subsection{Pertumbuhan Ekonomi}

Konsep dasar pertumbuhan ekonomi adalah peningkatan hasil kegiatan ekonomi seluruh unit ekonomi dalam suatu wilayah atau bisa juga dikatakan pertumbuhan ekonomi suatu wilayah adalah peningkatan produk domestik regional bruto (PDRB) dimana produk atau hasil kegiatan ekonomi dari seluruh unit ekonomi domestik adalah dalam wilayah kekuasaan atau administratif seperti negara, provinsi, atau kabupaten. 


\subsection{Kemiskinan}

Fenomena kemiskinan merupakan sesuatu yang kompleks, dalam arti tidak hanya berkaitan dengan dimensi ekonomi saja tetapi juga dengan dimensi-dimensi lain diluar ekonomi. Namun selama ini kemiskinan lebih sering dikonsepsikan dalam konteks ketidakcukupan pendapatan dan harta (lack of income and assets) untuk memenuhi kebutuhan-kebutuhan dasar seperti pangan, sandang, perumahan, pendidikan dan kesehatan, yang mana semuanya berada dalam lingkup dimensi ekonomi. Menurut Sen [4] kemiskinan adalah kegagalan untuk berfungsinya beberapa kapabilitas dasar atau dengan kata lain seseorang dikatakan miskin jika kekurangan kesempatan untuk mencapai/mendapatkan kapabilitas dasar ini. Sen [5] menyatakan bahwa kemiskinan jangan dianggap hanya sebagai pendapatan rendah (low income), tetapi harus dianggap sebagai ketidakmampuan kapabilitas (capability handicap).

\subsection{Ketimpangan Pendapatan}

Alesina dan Rodrik dalam Hajiji [6] menyatakan bahwa ketimpangan pendapatan akan menghambat pertumbuhan. Hal ini karena ketimpangan menyebabkan kebijakan redistribusi pendapatan yang tentunya akan mahal. Indeks Gini adalah murni ukuran statistik untuk variabilitas dan ukuran normatif untuk mengukur ketimpangan. Wodon dan Yitzhaki [7] mengungkapkan kelebihan utama indeks Gini, yaitu:

1. Sebagai ukuran statistik untuk variabilitas, indeks Gini bisa digunakan untuk menghitung pendapatan negatif, ini adalah salah satu sifat yang tidak dimiliki oleh sebagian ukuran ketimpangan.

2. Indeks Gini juga bisa digambarkan secara geometris sehingga lebih mudah untuk diamati dan dianalisis.

3. Indeks Gini memiliki dasar teori yang kuat. Sebagai indeks normatif, indeks Gini bisa merepresentasikan teori kemiskinan relatif. Indeks Gini juga bisa diturunkan sebagai ukuran ketimpangan berdasarkan aksioma-aksioma keadilan sosial.

\subsection{Model Data Panel}

Menurut Gujarati dan Porter [8] terdapat tiga metode pendekatan yang dapat dilakukan untuk mengestimasi model regresi dengan data panel yaitu model gabungan, model pengaruh tetap, dan model pengaruh acak. Model panel pengaruh gabungan (common effect), persamaan modelnya sama dengan regresi linier biasa yaitu: 


$$
Y_{i t}=\beta_{0}+\sum_{j=1}^{k} \beta_{j} X_{j i t}+\varepsilon_{i t}
$$

Persamaan model panel pengaruh tetap (fixed effect) adalah

$$
Y_{i t}=\beta_{0}+\sum_{j=1}^{k} \beta_{j} X_{j i t}+\mu_{i}+\varepsilon_{i t}
$$

Sedangkan, persamaan model panel pengaruh acak (random effect):

$$
Y_{i t}=\beta_{0 i}+\sum_{j=1}^{k} \beta_{j} X_{j i t}+\varepsilon_{i t}
$$

dengan $\beta_{0 i}=\beta_{0}+\mu_{i}$

Langkah-langkah mendapatkan model terbaik dari data panel yaitu :

1. Penentuan model estimasi :

- Tanpa uji formal

Jika $T>N$ maka gunakan fixed effect model

Jika $T<N$ maka gunakan random effect model

Dilihat juga dari $R^{2}$, SSE, serta uji $F$ dan $t$ yang signifikan

- Dengan uji formal

a. Chow test

$H_{0}: v_{1}=v_{2}=\ldots=v_{N}=0=($ common effect model $)$

$H_{1}$ : minimal ada satu nilai $v_{i}$ yang tidak sama dengan nol (fixed effect model)

Statistik uji:

$$
F_{\text {hitung }}=\frac{R_{\text {fixed }}^{2}-R_{\text {pooled }}^{2} / N}{1-R_{\text {fixed }}^{2} /(N T-N-K-1)}
$$

dengan $K$ : banyak parameter dari $X$

Daerah penolakan : $F_{\text {hitung }}>F(\alpha, N,(N T-N-K-1))$

Jika hasilnya tolak $H_{0}$ maka lanjut pengujian model fixed effect model atau random effect model. 
b. Hausman test

$H_{0}: E\left(v_{i} \mid X_{1}, X_{2}, \ldots, X_{k}\right)=0$ (random effect model)

$H_{0}: E\left(v_{i} \mid X_{1}, X_{2}, \ldots, X_{k}\right) \neq 0$ (fixed effect model)

Statistik uji :

$$
m=\hat{q}[\operatorname{var}(\hat{q})]^{-1} \hat{q}
$$

dengan $\hat{q}=\hat{\beta}_{\text {fixed }}-\hat{\beta}_{\text {random }}$ dan $k$ adalah jumlah variabel bebas.

Daerah penolakan : $m>X_{(\alpha, k)}^{2}$

2. Menentukan model terbaik dari data panel apakah menggunakan model Common Effect Model, Fixed Effect Model, atau Random Effect Model.

\subsection{Evaluasi Model}

1. Pengujian koefisien regresi secara simultan (Uji $F)$

Pengujian koefisien regresi secara simultan digunakan untuk melihat apakah variabel bebas secara simultan (bersama-sama) mempengaruhi variabel tak bebas.

$H_{0}: \beta_{1}=\beta_{2}=\beta_{3}=\beta_{4}=0$

$H_{1}$ :minimal ada satu $\beta_{i} \neq 0$

Statistik uji :

$$
F=\frac{M S R}{M S E}
$$

Daerah penolakan : $F>F_{\text {tabel }}$ atau probabilitas kurang dari $\alpha$

2. Pengujian Koefisien Regresi Secara Parsial (Uji $t$ )

Pengujian koefisien regresi secara parsial digunakan untuk melihat pengaruh dari masing-masing variabel bebas secara parsial terhadap variabel tak bebas dalam model dengan mengasumsikan bahwa variabel lainnya konstan.

$H_{0}: \beta_{i}=0$

$H_{1}: \beta_{i} \neq 0$

dengan $i$ : inflasi, PDRB, UMP, DL 
Statistik uji :

$$
t=\frac{\beta_{i}}{s\left(\beta_{i}\right)}
$$

Daerah penolakan : $t>\mathrm{t}_{(\alpha / 2 ; \mathrm{n}-1)}$ atau probabilitas kurang dari $\alpha$

\subsection{Uji Asumsi}

Menurut Gujarati dan Porter [8], metode estimasi model panel pengaruh acak (random effect) menggunakan metode generalized least square (GLS), sedangkan model panel pengaruh gabungan (common effect) dan model panel pengaruh tetap (fixed effect) menggunakan ordinary least square (OLS). Salah satu kelebihan metode GLS yaitu tidak perlu memenuhi asumsi klasik. Jadi, apabila model regresi menggunakan random effect maka tidak perlu dilakukan uji asumsi klasik. Sebaliknya, apabila digunakan model regresi common effect atau fixed effect maka perlu dilakukan uji asumsi klasik. Menurut Gujarati dan Porter [9] sangat kecil kemungkinan terjadi multikolinearitas pada data panel sehingga peneliti cukup melakukan uji autokorelasi dan uji heteroskedastisitas.

\subsection{Pro Poor Growth Index (PPGI)}

Kakwani dan Pernia [10] menyatakan bahwa konsep pro poor growth pertama kali diperkenalkan pada era 1950-an dan kemudian dipertegas oleh Chenery (1974). Konsep pro poor growth juga secara implisit dijelaskan dalam World Development Report 1990. Indeks ini memiliki beberapa kelebihan, antara lain:

1. Data yang diperlukan tidak terlalu sulit, sehingga mudah dihitung.

2. Indeks ini dapat digunakan untuk memformulasikan kebijakan-kebijakan pro poor pada tingkat makro dan mikro

3. Indeks ini bisa dihitung menurut sektor ekonomi ataupun wilayah.

Identifikasi pro-poor growth di Indonesia akan dilakukan menggunakan analisis pengaruh pertumbuhan ekonomi terhadap ketimpangan pendapatan dan tingkat kemiskinan. Dalam menganalisis mengenai keterkaitan pertumbuhan ekonomi dan ketimpangan pendapatan terhadap kemiskinan, penulis menggunakan konsep PPGI. Untuk mendapatkan PPGI penulis menganalisis terlebih dahulu pengaruh pertumbuhan ekonomi terhadap ketimpangan, pengaruh pertumbuhan ekonomi terhadap kemiskinan. Identifikasi melalui analisa data panel melalui perhitungan pengaruh pada kemiskinan 
akibat dari adanya perubahan rata-rata pendapatan dan distribusinya. Diperlukan adanya identifikasi terhadap dampak dari pertumbuhan ekonomi terhadap kemiskinan ketika distribusi pendapatan tidak berubah (ketimpangan pendapatan konstan), dan pengaruh redistribusi terhadap kemiskinan (ketimpangan pendapatan berubah). Model analisa dikembangkan oleh Woodon [11], sebagai berikut:

$\log$ GINI $_{i t}=\alpha+\beta \log$ PDRBkapita $i t+\alpha_{k}+\varepsilon_{i t}$

(Model 1)

$\log _{P P M_{i t}}=\omega+\gamma \log P D R B k_{\text {apita }}+\delta \log _{i t} \operatorname{SINI}_{i t}+\omega_{k}+\varepsilon_{i t}($ gross impacts) (Model 2)

${\log P P M_{i t}}=\varphi+\lambda \log$ PDRBkapita $i t+\varphi_{k}+\varepsilon_{i t}$ (net Impacts)

(Model 3)

Pada penelitian ini penulis menggunakan data variabel berupa persentase penduduk miskin, PDRB perkapita, indeks pembangunan manusia (IPM), tingkat pengangguran, dan Gini rasio 33 provinsi di Indonesia dari tahun 2010-2015. Data diperoleh dari Badan Pusat Statistik.

\section{Hasil dan Pembahasan}

\subsection{Analisis Data Panel: Faktor-faktor yang Memengaruhi Persentase Penduduk Miskin di Indonesia}

Untuk mengetahui faktor-faktor yang memengaruhi persentase penduduk miskin di Indonesia, maka peneliti menerapkan analisis regresi data panel terhadap 198 total observasi yang terdiri atas 6 periode waktu yang terjadi pada tahun 2010 sampai tahun 2015 dan 33 provinsi di Indonesia. Sebelum melakukan estimasi, dilakukan pemilihan model terbaik melalui beberapa uji.

Melalui uji Chow, dengan signifikansi 5\% diketahui bahwa nilai Chi-Square sebesar 0,00 menolak hipotesis null yang menyatakan model terbaik adalah dengan menggunakan common effect model, sehingga dalam uji Chow dapat disimpulkan model terbaik adalah dengan menggunakan fixed effect model. Kemudian dilakukan uji Hausman pada tingkat signifikansi 5\%, dan diketahui bahwa nilai Chi-Square menerima hipotesis null. Hal ini menunjukkan bahwa model yang terbaik adalah dengan menggunakan random effect model (REM). Model yang akan terbentuk adalah sebagai berikut:

$$
P P M_{i t}=\alpha+\beta_{1} \ln \left(P_{D R B k a p i t a}\right)+\beta_{2} I P M_{i t}+\beta_{3} T P T_{i t}+\beta_{4} \text { Gini }_{i t}+\varepsilon_{i t}
$$

Berdasarkan pengujian terhadap model, estimasi persamaan secara umum yang berlaku di Indonesia adalah sebagai berikut: 


$$
P P M_{i t}=74.87805-0.928034 \ln (\text { PDRBkapita })
$$

Menggunakan uji secara parsial, dari empat variabel, yaitu produk domestik regional bruto (PDRB) per kapita, indeks pembangunan manusia (IPM), tingkat pengangguran terbuka (TPT), dan Gini ratio, yang diperkirakan dapat berpengaruh terhadap kemiskinan di Indonesia, dengan tingkat signifikansi sebesar 5\%, hanya PDRB per kapita yang secara signifikan mempengaruhi persentase penduduk miskin di Indonesia, sementara IPM, TPT, dan Gini ratio tidak mempengaruhi. Namun, dengan melakukan uji secara bersama-sama, keempat variabel tersebut mempengaruhi persentase penduduk miskin secara signifikan.

Jika dengan menganggap PDRB per kapita pada kondisi yang konstan, maka persentase penduduk miskin di Indonesia mencapai 74,88\%. Namun, ketika terdapat peningkatan PDRB per kapita sebesar 1 satuan, maka akan mempengaruhi secara negatif dengan menurunkan penduduk miskin sebesar 0,93\%. Model persamaan untuk estimasi persentase penduduk miskin, variabel-variabel independen mampu menjelaskan model sebesar $25,74 \%$. Hal ini masih dikategorikan wajar karena hanya terdapat satu variabel yang berpengaruh secara signifikan yang kemudian disebut sebagai pertumbuhan ekonomi terhadap persentase kemiskinan sesuai dengan pernyataan Kuznet, dimana pertumbuhan ekonomi dan kemiskinan memiliki korelasi yang kuat. Pada tahap awal proses pembangunan, jumlah orang miskin cenderung meningkat, namun secara bertahap akan berkurang sampai pada tahap akhir pembangunan tersebut.

Peningkatan PDRB per kapita dalam hal ini mampu menjelaskan pertumbuhan ekonomi tiap penduduk secara nyata. Ketika terjadi peningkatan PDRB per kapita di Indonesia maka perekonomian juga turut membaik. Membaiknya perekonomian di Indonesia dapat dilihat melalui berkembangnya infrastruktur dan aktivitas ekonomi masyarakat di Indonesia. Membaiknya perekonomian Indonesia juga dapat dilihat melalui peningkatan konsumsi masyarakat yang secara tidak langsung menyatakan bahwa ada peningkatan pendapatan dari masyarakat itu sendiri. Peningkatan pendapatan per kapita ini cukup dapat menjelaskan penurunan persentase kemiskinan di Indonesia.

Dari pengujian terhadap model, diketahui bahwa provinsi D.I. Yogyakarta memiliki koefisien dengan efek terbesar terhadap persentase penduduk miskin, yaitu sebesar 11,45, sementara provinsi dengan koefisien terendah adalah provinsi Kalimantan Selatan sebesar $-7,7$. 


\subsection{Uji Asumsi Klasik}

Uji asumsi klasik yang dilakukan terhadap model adalah uji normalitas dan multikolinieritas. Dalam uji normalitas, dengan melihat nilai Jarque-Bera dan probabilitas, pada signifikansi 5\%, data keempat variabel berdasarkan 33 provinsi di Indonesia menerima hipotesis null yang menyatakan bahwa data tersebar secara normal.

Dengan melihat matriks varians kovarians, dapat dilihat apakah pada model terjadi multikolinieritas atau tidak. Jika nilai korelasi antar variabel yang berbeda memiliki nilai kurang dari 0,8 , maka dapat dikatakan terjadi multikolinieritas dalam model tersebut. Berdasarkan uji multikolinieritas, tidak ditemukan nilai korelasi antar variabel lebih dari 0,8. Hal ini menunjukkan bahwa dalam model tidak ditemukan terjadinya multikolinieritas.

\subsection{Analisis pro poor growth index (PPGI)}

Dari hasil perhitungan didapatkan hasil sebagai berikut :

Model 1 diregresi menggunakan model random effect. Model random effect dipilih setelah melalui pengujian yang menyimpulkan bahwa model random effect lebih baik daripada common effect ataupun fixed effect (uji Chow dan uji Hausman). Setelah dilakukan uji asumsi klasik random effect memenuhi kriteria asumsi yaitu berdistribusi normal dan tidak ada multikolinieritas.

Tabel 1 Pengaruh Pertumbuhan Ekonomi Terhadap Ketimpangan Pendapatan

\begin{tabular}{rcc}
\hline$R^{2}$ & $F$-statistik & $\beta$ \\
\hline 0,9889 & $232,2844^{*}$ & $0,0219^{*}$ \\
\hline
\end{tabular}

Hasil pengolahan menunjukkan bahwa nilai $\beta$ yang didapat sebesar 0,0219 artinya peningkatan PDRB per kapita sebesar 1 persen akan meningkatkan ketimpangan pendapatan sebesar 0,0219 persen. Peningkatan ketimpangan ini karena pertumbuhan ekonomi yang dicapai tidak dinikmati secara merata oleh seluruh kelompok penduduk di Indonesia baik kaya maupun miskin. Hasil ini sejalan dengan yang didapatkan oleh Lin [12], Hidayat dan Patunru [13], dan Hajiji [6]. Hasil di atas menunjukkan bahwa Indonesia pada tahun 2010-2015 tidak sesuai dengan teori Kuznets.

Model 2 diregresi menggunakan model random effect. Model random effect dipilih setelah melalui pengujian yang menyimpulkan bahwa model random effect lebih 
baik daripada common effect ataupun fixed effect (uji Chow dan uji Hausman). Setelah dilakukan uji asumsi klasik random effect memenuhi kriteria asumsi yaitu berdistribusi normal dan tidak ada multikolinieritas.

Tabel 2 Pengaruh Pertumbuhan Ekonomi dan Ketimpangan Pendapatan Terhadap Kemiskinan

\begin{tabular}{cccc}
\hline$R^{2}$ & $F$-statistik & $\Gamma$ & $\delta$ \\
\hline 0,3157 & $44,9778^{*}$ & $-0,0019$ & $-4,2309^{*}$
\end{tabular}

Tabel 2 menunjukkan bahwa ketimpangan pendapatan berhubungan negatif dengan tingkat kemiskinan, artinya setiap penurunan tingkat ketimpangan sebesar 1 persen akan meningkatkan kemiskinan sebesar 4,2309. Pengurangan ketimpangan yang terjadi dari pertumbuhan ekonomi ini mengindikasikan adanya redistribusi pendapatan dari kelompok tidak miskin ke kelompok miskin, namun sayangnya pengurangan ketimpangan ini justru meningkatkan kemiskinan. Artinya, redistribusi pendapatan terjadi pada kelompok tidak miskin yang jaraknya dekat dengan garis kemiskinan ke kelompok miskin sehingga justru mendorong mereka jatuh ke bawah garis kemiskinan, hal ini sesuai dengan penelitian Laksani [14]. Pertumbuhan ekonomi akan menurunkan kemiskinan dengan elastisitas sebesar 0,0019 tetapi secara statistik tidak signifikan. Dalam penelitian Hajiji [6] dikatakan bahwa efek pertumbuhan ekonomi akan selalu negatif yaitu mengurangi kemiskinan sedangkan efek ketimpangan bisa positif ataupun negatif, jika negatif maka pertumbuhan juga menyebabkan distribusi pendapatan berubah dan menguntungkan kelompok yang tidak miskin.

Model 3 diregresi menggunakan model fixed effect. Model fixed effect dipilih setelah melalui pengujian yang menyimpulkan bahwa model fixed effect lebih baik daripada common effect ataupun random effect (uji Chow dan uji Hausman). Setelah dilakukan uji asumsi klasik fixed effect ternyata memiliki heteroskedastisitas dalam struktur matriks variance-covariance nya dan juga terdapat cross sectional correlation oleh karena itu model estimasi yang digunakan adalah seemingly unrelated regression (SUR). 
Tabel 3 Pengaruh Pertumbuhan Ekonomi dan Ketimpangan Pendapatan Terhadap

Kemiskinan

\begin{tabular}{ccc}
\hline$R^{2}$ & $F$-statistik & $\lambda$ \\
\hline 0,3157 & $445,3806^{*}$ & $-0,1095^{*}$ \\
\hline
\end{tabular}

Berdasarkan Tabel 3 dapat diketahui bahwa peningkatan pertumbuhan PDRB per kapita dapat menurunkan kemiskinan sebesar 0,1095 persen. Hal ini berarti bahwa pertumbuhan ekonomi dan ketimpangan pendapatan secara bersama-sama akan menurunkan kemiskinan sebesar 0,1095 persen. Hasil ini sejalan dengan penelitian Lin [12], Hajiji [6], dan Laksani [14].

Tabel 4. Hasil Penelitian Pertumbuhan Ekonomi dan Ketimpangan Pendapatan

\begin{tabular}{lll}
\hline $\begin{array}{l}\text { Efek pertumbuhan } \\
\text { pendapatan }(\beta)\end{array}$ & $\begin{array}{l}\text { Efek ketimpangan } \\
\text { pendapatan }(\beta \mathrm{x} \delta)\end{array}$ & $\begin{array}{l}\text { Elastisitas netto kemiskinan } \\
\text { terhadap pertumbuhan } \\
\text { ekonomi }(\lambda)\end{array}$ \\
\hline$-0,0019$ & $-0,0929$ & $-0,1095$
\end{tabular}

Berdasarkan Tabel 4 dapat diketahui kemiskinan akan turun sebesar 0,0019 persen jika ada pertumbuhan ekonomi sebesar 1 persen dan akan turun sebesar 0,1095 persen ketika adanya penurunan ketimpangan dan pertumbuhan ekonomi.

$$
\phi=\frac{\gamma}{\lambda}=\frac{-0,1095}{-0,0019}=57,6316
$$

Hasil PPGI menunjukkan bahwa Indonesia tergolong pro poor. Hasil ini sesuai dengan penelitian dari Suhartini [15] yang menyimpulkan bahwa Indonesia sudah tergolong pro poor dari tahun 2008-2009. Meskipun pertumbuhan ekonomi di Indonesia tergolong pro poor, namun nilai elastisitas bruto dan neto kemiskinan terhadap pertumbuhan ekonomi Indonesia kurang elastis. Sebagai akibatnya, pengurangan kemiskinan yang didorong dari adanya pertumbuhan ekonomi pun tidak terlalu besar. Selain itu, pengaruh pertumbuhan ekonomi terhadap kemiskinan melalui efek ketimpangan pendapatan pun tergolong lemah. 


\section{Kesimpulan}

Pertumbuhan ekonomi masih terjadi di Indonesia yang ditandai dengan PDRB masing-masing provinsi yang cenderung meningkat. Namun tingkat kesejahteraan rakyat masih rendah yang ditandai dengan peningkatan tingkat pengangguran terbuka dan ketimpangan pendapatan yang masuk kategori sedang. Meskipun begitu, kesejahteraan rakyat di bidang kesehatan dan pendidikan semakin membaik yang ditandai dengan peningkatan IPM.

Tingkat kemiskinan provinsi-provinsi di Indonesia dipengaruhi secara signifikan oleh PDRB dengan menurunkan penduduk miskin sebesar 0.93\%. Selain itu, IPM, PDRB, TPT, dan rasio Gini secara bersama-sama memengaruhi kemiskinan provinsiprovinsi di Indonesia dengan signifikan. Serta D.I. Yogyakarta memiliki koefisien dengan efek terbesar terhadap persentase penduduk miskin, yaitu sebesar 11,45, sementara provinsi dengan koefisien terendah adalah provinsi Kalimantan Selatan sebesar -7,7.

Dari hasil PPGI diketahui bahwa Indonesia telah pro poor. Namun, karena nilai elastisitasnya kecil maka pengurangan kemiskinan yang didorong dari adanya pertumbuhan ekonomi pun tidak terlalu besar.

\section{Daftar Pustaka}

[1] Todaro, M.P. and Smith, S.C.. Economic Development. Twelfth Edition. New Jersey. 2014.

[2] Bourgoignon, F. The Poverty-Growth-Inequality Triangle. Washington. 2004.

[3] Badan Pusat Statistik. Statistik Indonesia, Tahun 2010-2016. Jakarta. 2017.

[4] Sen, A. A sosiological approach to the meaurement of poverty: a reply to professor peter townsend. Oxford Economic Papers 37: 669-676. 1985.

[5] Sen, A. The political economy of targeting. Di dalam Van de Walle D, Nead K, editor. Public Spending and The Poor. The John Hopkins University Press. Baltimore. 1995.

[6] Hajiji, A. Analisis Pro-Poor Growth Di Indonesia Melalui Identifikasi Pengaruh Pertumbuhan Ekonomi Terhadap Ketimpangan Pendapatan Dan Kemiskinan. Bogor. 2010.

[7] Wodon, Q and Yitzhaki, S. Inequality and Social Welfare. Published in: A Sourcebook for Poverty Reduction Strategies, Vol. 1, (April 2002): pp. 75-104. Germany. 2002.

[8] Gujarati, D dan Porter, D. Dasar-Dasar Ekonometrika (Terjemahan). Salemba Empat. Jakarta. 2009.

[9] Gujarati, D dan Porter, D. Dasar-Dasar Ekonometrika (Terjemahan), Edisi Lima, Buku Dua. Penerbit Salemba Empat. Jakarta. 2012.

[10] Kakwani, N and Pernia Ernesto M. What is Pro Poor Growth?. Asian Development Bank, Vol. 18, No.1. pp. 1-16. 2000. 
[11] Wodon, Q. Growth, Poverty and Inequality: A Region Panel for Banglades. Policy Research Working Paper No. 2072. World Bank South Asia Region. 1999.

[12] Lin, B. Q. Economic Growth, Income Inequality, and Poverty Reduction in people's Republic of China. Asian Development Review. 20:105-124. 2003.

[13] Hidayat, S. dan Patunru, A.A. Pertumbuhan Ekonomi, Ketidakmerataan Pendapatan dan Kemiskinan: Estimasi Parameter Elastisitas Kemiskinan Tingkat Provinsi di Indonesia tahun 1996-2005. Universitas Indonesia. Jakarta. 2007.

[14] Laksani, C.S. Analisis Pro-Poor Growth Di Indonesia Melalui Identifikasi Pengaruh Pertumbuhan Ekonomi Terhadap Ketimpangan Pendapatan Dan Kemiskinan. Universitas Indonesia. Jakarta. 2010.

[15] Suhartini, A.M. Pro Poor Growth Tingkat Provinsi Di Indonesia. Institut Pertanian Bogor. Bogor. 2011. 